FORMATION Formation emploi

Revue française de sciences sociales

130 | Avril-Juin 2015

L'essor des compétences non académiques

\title{
Edito : Quand les compétences sont aussi non académiques
}

Jean-Frédéric Vergnies

\section{(2) OpenEdition}

1 Journals

Édition électronique

URL : https://journals.openedition.org/formationemploi/4391

DOI : 10.4000/formationemploi.4391

ISSN : 2107-0946

Éditeur

La Documentation française

Édition imprimée

Date de publication : 10 juin 2015

Pagination : 1-2

ISSN : 0759-6340

Référence électronique

Jean-Frédéric Vergnies, «Edito : Quand les compétences sont aussi non académiques », Formation emploi [En ligne], 130 | Avril-Juin 2015, mis en ligne le 10 juin 2015, consulté le 21 septembre 2021. URL : http://journals.openedition.org/formationemploi/4391 ; DOI : https://doi.org/10.4000/

formationemploi.4391

(c) Tous droits réservés 


\title{
Quand les compétences sont aussi non académiques
}

\author{
Jean-Frédéric Vergnies \\ Rédacteur en chef
}

La logique compétence a, dit-on, gagné l'École comme l'entreprise. Gestion, bilan, blocs, référentiels... sont associés au terme " compétences ». Ainsi, la place des compétences dans la relation formation-emploi pourrait parfois paraitre " aller de soi ».

Pourtant, cette notion est loin d'être stabilisée et sa mesure soulève maintes questions. Un numéro précédent de Formation Emploi rappelait, en $2007^{1}$, combien la compétence, loin d'être uniquement personnelle, est un phénomène social et collectif. On peut être compétent dans un certain contexte et ne plus l'être lorsque le contexte, l'organisation, le collectif de travail... changent. Ainsi en est-il, par exemple, de certains sportifs donc les compétences ne seront pas nécessairement transférables dans la scolarité ou la carrière professionnelle.

Dans ce numéro, on explore la distinction entre compétences académiques et non académiques. Cette notion de compétences non académiques est elle aussi en débat ; selon les approches et les disciplines, elle peut se décliner en compétences non cognitives, comportementales, sociales, émotionnelles, relationnelles, positionnelles, voire esthétiques... Ce numéro vise donc à poser des premiers jalons dans l'exploration de cette notion.

Marie Duru-Bellat ouvre une discussion générale sur cette notion qui apparaît mobilisée dans les analyses et les pratiques du marché du travail. Ainsi, évaluer les compétences non académiques s'avère difficile. Pourtant, leur prise en compte par les acteurs de la formation apparaît incontournable, surtout si l'on souhaite que les compétences requises, notamment au travail, ne soient pas le privilège des " héritiers »... et soient l'objet d'apprentissages.

1 «Les usages sociaux de la compétence », Formation Emploi, nº 99, 2007. 